\begin{tabular}{l}
$\begin{array}{c}\text { Yanbu Journal } \\
\text { of }\end{array}$ \\
$\begin{array}{l}\text { Engineering } \\
\text { and Science }\end{array}$ \\
\hline \hline ISSN: $1658-5321$
\end{tabular}$\quad$ Vol. 14, June $2017(1438 \mathrm{H})$

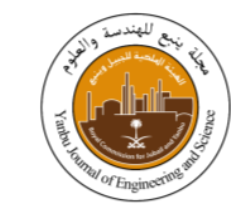

\title{
EFFECT OF THERMOPLASTIC POLYESTER BLEND ON THE MECHANICAL, THERMAL AND RHEOLOGICAL PROPERTIES OF POLYPROPYLENE
}

\author{
Aravinthan Gopanna ${ }^{1,2}$ and Murthy Chavali ${ }^{3}$ \\ ${ }^{1}$ Advanced Materials Laboratory, Yanbu Research Center, Royal Commission for Yanbu-Colleges and Institutes, P. O. Box 30436, \\ Yanbu Industrial City 41912, Kingdom of Saudi Arabia \\ ${ }^{2}$ Department of Chemical Engineering, Vignan's Foundation for Science, Technology and Research University (VFSTRU; Vignan's \\ University), Vadlamudi, Guntur 522213 Andhra Pradesh, India \\ ${ }^{3}$ Division of Chemistry, Department of Sciences and Humanities, Vignan's Foundation for Science, Technology and Research University \\ (VFSTRU; Vignan's University), Vadlamudi, Guntur 522213 Andhra Pradesh, India \\ E-mail:gopannad@rcyci.edu.sa
}

\begin{abstract}
The objective of this study is the preparation and characterization of ternary blends consisting of polypropylene with poly(ethylene terephthalate) poly(butylene terephthalate) blends with a ratio of poly(ethylene terephthalate) to poly(butylene terephthalate) concentration as 1 . Poly(ethylene terephthalate) polypropylene blend, poly (butylene terephthalate) polypropylene blend and poly(ethylene terephthalate) poly (butylene terephthalate) polypropylene ternary blends were prepared by melt blending technique using a co-rotating twin-screw extruder. Acrylic acid grafted polypropylene (PP-g-AA) was used as compatibilizer. The mechanical, thermal, rheological and morphological behavior of the homopolymers, binary blends and ternary blends were investigated. The results confirmed that the ternary blends show enhanced mechanical and thermal properties compared to that of poly(ethylene terephthalate) polypropylene blend and poly(butylene terephthalate) polypropylene blend. The morphology study showed the homogenous dispersion of thermoplastic polyesters component in ternary blends lead to better interaction between polypropylene and thermoplastic polyester phases and thereby improved the overall mechanical properties of ternary blends. The rheological behavior of ternary blends with high viscosity at low shear rates useful for thermoforming applications.
\end{abstract}

Keywords: Polymer blends, Poly(ethylene terephthalate), Poly(butylenes terephthalate), Polypropylene, Compatibilization, Rheology.

\section{INTRODUCTION}

Poly(ethylene terephthalate) (PET) and Poly(butylenes terephthalate) (PBT) are very important commercial aromatic-aliphatic polyester resins suitable for a wide field of engineering applications. PET is used for the fabrication of molded articles, fibers and films. PBT is used for injection molded products.
However, a major shortcoming of PET and PBT resins is their brittleness. The commercial growth of thermoplastic polyesters has been very rapid among the thermoplastic resins because of their broad range of properties, including high heat distortion temperature, high rigidity, excellent surface appearance, stable electrical insulation properties, good chemical resistance, fast 
processing cycles and excellent mold flow. Polypropylene is one of the widely used thermoplastic materials due to its low cost, good availability and wide spectrum of properties. Blending of thermoplastic polyesters with polypropylene is a useful way to upgrade the mechanical properties, dyeability and oil resistance of polypropylene. These blends also offer price and property advantages [1,2]. When two or more polymers are blended together, often they are not compatible with each other, which ensuing blend with inadequate properties for most end applications. Compatibilizers are used to reduce interfacial energy between two polymers in order to increase adhesion as well as results in finer dispersion and stable morphologies for the blends [2]. In general, polyolefin containing a functionalized group reacts with hydroxyl and/or carboxyl groups of polyesters act as a compatibilizer for polyolefin/polyesters blends. Maleic anhydride grafted polypropylene (PP-g-MAH) [3-5], glycidyl methacrylate grafted polypropylene (PP-g-GMA) [5-8], acrylic acid grafted polypropylene (PP-g-AA) [3,9-11], oxazoline grafted polypropylene (PP-g-Oxa) [12], polypropylene grafted with 2hydroxyethyl methacrylate - isophorone diisocyanate (PP-g-HI) [13], high density polyethylene grafted with the blocked isocyanate group (HDPE-g-BHI) [14], polypropylene grafted with phenol formaldehyde (PP-g-PF) [15], ethylene acrylic acid (EAA) [16], ethylene vinyl acetate (EVA) [16], dual system of maleic anhydride-grafted polypropylene (PP-g-MAH) and a multifunctional epoxy resin [17], hydroxylated ethylene vinyl acetate [18], bismaleimide (BMI) [19], ethylene-coglycidyl methacrylate copolymer (EGMA) [20], hydrogenated styrene/butadiene/styrene copolymer (SEBS) [21], hydrogenated styrene/butadiene/styrene copolymer grafted with maleic anhydride (SEBS-g-MAH) [2124], hydrogenated styrene/butadiene/styrene copolymer grafted with glycidyl methacrylate (SEBS-g-GMA) [21,23], ionomer resins [25], Maleic anhydride grafted polyethylene-octene elastomer (POE-g-MA) [26], etc are the compatibilisers used for improvement of mechanical properties and regular morphologies in polymer blends. Polypropylene-grafted-glycidyl methacrylate (PP-g-GMA) as compatibilizer in blends of isotactic polypropylene (iPP) and poly(ethylene terephthalate) (PET) was prepared by [6]. The morphological observation showed that addition of a polypropylene-grafted-glycidyl methacrylate increases the viscosity ratio and decreases the interfacial tension between $\mathrm{PPP}$ and PET as well as decrease the size of PET phase in the unstretched blends [6]. Blends of high density polyethylene (HDPE) and poly(ethylene terephthalate) (PET) exhibited poor mechanical properties due to the incompatibility of these two components. The addition of small amounts of triblock copolymer Kraton G 1652 significantly improved the ductility of these incompatible blends [27]. Guerrero et al studied the mechanical properties of poly(ethylene terephthalate) (PET) /High-density polyethylene (HDPE) with and without Surlyn as a compatibilizer. SEM studies showed homogeneous morphology for the compatibilized blends than that of the uncompatibilized blends. The increases in elongation at break and impact strength in the compatibilized blends concluded that Surlyn really acts as a compatibilizing agent between PET and HDPE [28]. Boutevint et al, studied HDPE/PET blends with various graft copolymers compatibilizing agents and found that the PEgMA and PEgGMA copolymers 
provided effective compatibilization to the blend system. The compatibilizing effect leads to $60 \%$ increase of breaking strength and $150 \%$ increase of elongation [29]. [30] prepared immiscible binary blends of cellulose acetate propionate and poly(butylene terephthalate) in the composition range of 515 wt $\%$ for cellulose acetate propionate in the form of films and fibers by compression molding and spinning, respectively. It was found that because of their immiscibility and poor adhesion, the viscosities of the binary blends were lower than that of the pure PBT at the same shear rate. In films, the amorphous cellulose acetate propionate was present as dispersed particles in the PBT matrix; but in the spun fibers cellulose acetate propionate became as rods. Also, the presence of the amorphous cellulose acetate propionate resulted in a decrease of tensile strength and an increase in the elongation at break for the fibers [30]. PET and PBT form a miscible blend system. Mishra and Deopura have predicted theoretical compatibility of PET and PBT blends through thermodynamic considerations [31]. In another study, they also reported that although PET is compatible with PBT in the amorphous phase, it formed separate crystals rather than co-crystals. Therefore, these blends can give significantly different properties than the PET or PBT depending upon composition and processing conditions [32]. Stein and coworkers have studied the miscibility and morphology of PET/PBT blends using calorimetric (DSC), infrared (IR) spectroscopy and wide-angle Xray diffraction (WAXD) techniques. IR studies showed that the spectra of the blend were basically a superposition of influences from the individual components. DSC studies revealed distinct melting points for the PET and PBT component. WAXD scans on melt PET/PBT blends also showed diffraction characteristic of the both species. No appreciable shifts in peak positions nor new diffractions were observed. These results evidenced that the formation of cocrystallization not occurred in PET/PBT system [33]. Avramova has reported single glass transition temperature, $\mathrm{T}_{\mathrm{g}}$ indicating the miscibility of PET and PBT segments in amorphous phase. There are hardly any data on the mechanical properties of PET/PBT system over entire concentration range [34]. Tao et al investigated the compatibility and morphology of the crystalline PBT/PET blends. They reported that PBT component helps to increase the crystallinity of the PBT/PET blends and interlocked network morphology [35]. Mantia et al prepared blend of PP with PET as dispersed phase, which has been compatibilized with SEBS copolymer grafted with maleic anhydride and investigated the effect of compatibilizer on blend's morphology and mechanical properties. SEBS copolymer grafted with maleic anhydride evident very small size of the dispersed phases with better adhesion with the matrix phase. The more refined morphology of the compatibilized blend influences the mechanical properties of the PP/PET blend with increased elongation at break and decreased modulus and tensile strength due to the presence of the rubbery compatibilizer [36]. Aravinthan and Kale prepared PET/PBT blends over the entire composition range through melt blending technique and investigated mechanical, thermal, electrical and rheological properties. PET/PBT blends showed better mechanical properties for all the compositions compared to the pure homopolymers. The incorporation of PBT improved the processability of the blends. DSC data showed that the melting characteristics of one phase in the PET/PBT blends were influenced by the presence of the 
other. The single $T_{g}$ value was observed due to miscibility of the amorphous phase of PET and PBT. SEM study reported co-continuous and fibrillar behavior for 50:50 PET/PBT blend compositions. The 50:50 PET/PBT blend considered as the optimum composition based on its mechanical, thermal, electrical and morphological properties compared to the pure homopolymers and other blend compositions [37]. In this research work, binary blends of PP with PET, $\mathrm{PBT}$ and ternary blends of $\mathrm{PP} /(\mathrm{PET} / \mathrm{PBT})$, where PET:PBT blend ratio was equal to 1 and using acrylic acid grafted PP (PP-g-AA) as compatibilizer and their characterisation are reported.

\section{EXPERIMENTAL}

\subsection{MATERIALS}

Commercial grades of Polypropylene (MFI 11 g/10 min @ 230 $\mathrm{C} / 2.16 \mathrm{~kg}$ ), Poly(ethylene terephthalate), RELPET, Grade G5801, Intrinsic viscosity (I.V.) $0.80 \mathrm{dl} / \mathrm{g}$ were procured from Reliance Industries Ltd., Mumbai, India and Poly(butylene terephthalate) ARNITE, Grade B-600 I.V. $1.40 \mathrm{dl} / \mathrm{g}, \mathrm{DSM}$ Engineering Plastics, India. Polypropylene grafted with acrylic acid (PP-gAA) was used as a compatibilizer [Uniroyal Chemical Ltd. (Grade Polybond 1002)].

\subsection{BLENDING}

Polypropylene was blended with PET, PBT and PET:PBT (50:50) blend. All the polyesters were dried in air circulating oven at $120^{\circ} \mathrm{C}$ for $8 \mathrm{hrs}$ prior to blending with PP. The blend compositions were PP75:PET25; PP75:PBT25;

P75:PET12.5:PBT12.5

(Ternary Blend I) and PP50:PET25:PBT25 (Ternary Blend II) in weight percentage. The blends were melt blended using co-rotating twin-screw extruder (Model MP 19 PC, APV BAKER, U.K.) having L/D ratio of 25:1. The screw speed was maintained at $40 \mathrm{rpm}$ and the temperature profile for compounding was $200^{\circ} \mathrm{C}, 215^{\circ} \mathrm{C}, 230^{\circ} \mathrm{C}$ and $245^{\circ} \mathrm{C}$ for four zones and $260^{\circ} \mathrm{C}$ for the die zone. The extrudate from the twin-screw extruder was water cooled and pelletized. The extruded pellets were dried and molded into standard ASTM specimens at a temperature profile of 200,240 and $280^{\circ} \mathrm{C}$ for the nozzle, by using microprocessor based injection-molding machine (Boolani Machineries Ltd., Mumbai, India).

\subsection{Mechanical Properties}

Tensile strength, flexural strength and flexural modulus were measured at ambient conditions using universal tensile testing machine (LR-50K, LLOYDS Instrument, U.K.), according to ASTM procedures. The crosshead speed was $50 \mathrm{~mm} / \mathrm{min}$ and $2.8 \mathrm{~mm} / \mathrm{min}$ for tensile tests (ASTM 638M-91) and flexural tests (ASTM 790M-92) respectively. The notch for impact test was cut using a motorized notch-cutting machine (Polytest model 1, Ray Ran, U.K.). Notched izod impact strength was measured at ambient conditions according to the ASTM D 256 method using an impact tester (Avery Dension, U.K.) with striking velocity of $3.46 \mathrm{~m} / \mathrm{s}$, employing 2.7J striker.

\subsection{THERMAL PROPERTIES}

\subsubsection{Heat Distortion Temperature (HDT)}

The specimens similar to those used for measuring flexural strength were used to determine heat deflection temperature (HDT) according to ASTM D 648, using HDT Vicat softening point apparatus (DAVENPORT, U.K).

\subsubsection{Differential Scanning Calorimeter (DSC)}

Melting and crystallization behavior of PET/PBT blends was studied using DSC-7 (Perkin Elmer, USA). Temperature calibration was performed using Indium as a reference $\left(T_{m}=156.60{ }^{\circ} \mathrm{C}\right.$ and Heat flow $=$ 
$28.5 \mathrm{~J} / \mathrm{g}$ ). The heating rate of the samples was $20^{\circ} \mathrm{C} / \mathrm{min}$ with a sample size between 7 to 13 mg using standard aluminum sample pan. The sample was maintained under nitrogen atmosphere.

\subsection{RHEOlogical Properties}

The melt rheology of the individual polymers and their blends was studied using a rotational rheometer (Haake RT 10, Germany), employing parallel plate sensor of diameter of $35 \mathrm{~mm}$ at $260^{\circ} \mathrm{C}$. The shear rate range was varied from $0.01-100 \mathrm{~s}^{-1}$. For higher shear rates, rheological measurements at $260^{\circ} \mathrm{C}$ were carried out using twin bore capillary rheometer (Rosand precicion, U.K.). The shear rate range was $100-10000 s^{-1}$. These capillary rheological data were subjected to Bagley and Rabinowitsch corrections.

\subsection{SEM MORPHOLOGY}

The morphological characteristics of $\mathrm{PP} /$ thermoplastic polyesters blends were examined by a scanning electron microscopy (SEM), (SHIMADZU SS - 550 Superscan, Japan). SEM samples were prepared by etching technique using phenol and tetracholoroethane mixture.

\section{RESULTS AND DISCUSSION}

\subsection{Mechanical Properties}

Table 1 depicts the tensile, flexural, impact and HDT data of PET, PBT and PET/PBT blends. PET:PBT; 40:60, 50:50 and 60:40 blends show better properties than virgin polymers as well as other PET:PBT blend compositions. It is interesting to note that all blend compositions shows increases in impact strength and flexural modulus. PET:PBT 50:50 blend has the highest impact strength and flexural modulus compared to that of homopolymers and other blends. The tensile strength as well as flexural strength for all blends and individual polymers is comparable.
The HDT of PBT is lower than that of PET. As the percentage of PET in PBT increased, the HDT also increased proportionately. In the previous publication of first author, the miscibility of amorphous portions of PBT with PET is reported and SEM photomicrographs showed the co-continuous morphology of PET:PBT 50:50 blend which leads for overall improvement in the mechanical properties [37]. Table 2 depicts the tensile, flexural, impact and HDT data of $\mathrm{PP} /$ thermoplastic polyesters binary and ternary blends. The tensile strength, flexural strength and flexural modulus of PP are lower than that of PET and PBT. However, the impact strength of PP is higher than that of PET and PBT. Binary blends shows only the marginal increases in the impact strength compared to thermoplastic polyester and marginal increases in the tensile strength compared to PP. Flexural strength and flexural modulus of binary blends are considerably increased than that of PP. The overall mechanical properties of ternary blend $\mathrm{I}$, is better than those of binary blends and PP alone. The HDT of all the blend compositions are comparable to that of $\mathrm{PP}$. Figure 1 and 2 represents the tensile strength and impact strength data of PET/PBT blends.

\subsection{Differential ScanNing CAlorimeter (DSC)}

Figure 3 and 4 shows DSC heating and cooling scans for PP, PET:PBT(50:50), PP:PET (75:25), PP:PBT (75:25) and PP:PET:PBT (75:12.5:12.5). The summary of heating and cooling scans for the pure homopolymers, binary blends and ternary blends are shown in Table 3. The peak melting point $\left(\mathrm{T}_{\mathrm{m}}\right)$ of $\mathrm{PP}, \mathrm{PBT}$ and PET at about $170^{\circ} \mathrm{C}, 229^{\circ} \mathrm{C}$ and $246^{\circ} \mathrm{C}$ respectively. The PET:PBT (50:50) blend, depression in the melting point peak of PBT is observed. The melting point peaks $\left(T_{m}\right)$ values of PET, $\mathrm{PBT}$ and $\mathrm{PP}$ in the blends composition are 
found to be relatively unchanged. The presence of individual melting temperatures of the polymers in all compositions with no significant $T_{m}$ depression indicated that PP, PET and PBT crystallized separately. DSC studies by Oyman and Tinçer reported similar trend of results [38]. The peak crystallization temperature for PP, PET and PBT are $102^{\circ} \mathrm{C}$, $151^{\circ} \mathrm{C}$ and $179^{\circ} \mathrm{C}$ respectively. The cooling scan data show crystallization temperature peak $\left(T_{c}\right)$ for respective component present in the blend compositions. The peak crystallization temperature for PP component in the blends composition is higher may be due to nucleating effect of thermoplastic polyester component. Total heats of crystallization for all binary and ternary blends are lower than that of PP. In binary and ternary I blend the heat of crystallization for polyesters component has reduced but for PP component has not been affected seriously. In overall the binary and ternary I blends would crystallize at higher temperature and crystallization become faster for these blend than that of thermoplastic polyester alone. The crystallinity $\left(\mathrm{X}_{\mathrm{c}}\right)$ was determined using the following equation [1]:

$$
\mathrm{X}_{\mathrm{c}}=\left(\Delta \mathrm{H}_{\mathrm{f}} / \Delta \mathrm{H}_{\mathrm{f} 100}\right) \times 100 \%
$$

Where, $\Delta \mathrm{H}_{\mathrm{f}}$ is the heat of fusion of the sample obtained calorimetrically and $\Delta \mathrm{H}_{\mathrm{f} 100}$ is the heat of fusion of a $100 \%$ polymer. $\Delta \mathrm{H}_{\mathrm{f} 100}=205 \mathrm{~J} / \mathrm{g}$ for PP, $\Delta \mathrm{H}_{\mathrm{f} 100}=140 \mathrm{~J} / \mathrm{g}$ for PET and PBT [39, 40]. Table 4 describes the crystallinity data for Polypropylene /Thermoplastic polyesters blends.

Table 1: Tensile, FleXural, Impact and HDT data of PET, PBT and PET/PBT BLENDS

\begin{tabular}{|c|c|c|c|c|c|c|}
\hline S.No. & $\begin{array}{l}\text { Compositions } \\
\text { (wt \%) }\end{array}$ & $\begin{array}{c}\text { Tensile } \\
\text { strength (MPa) }\end{array}$ & $\begin{array}{c}\text { Flexural } \\
\text { strength (MPa) }\end{array}$ & $\begin{array}{l}\text { Flexural modulus } \\
\qquad(\mathrm{MPa})\end{array}$ & $\begin{array}{c}\text { Impact } \\
\text { strength }(J / m)\end{array}$ & $\begin{array}{l}\text { HDT } \\
\left({ }^{\circ} \mathrm{C}\right)\end{array}$ \\
\hline 1 & PET 100 & $56 \pm 0.5$ & $76 \pm 0.5$ & $2105 \pm 10$ & $25 \pm 0.5$ & $78 \pm 1$ \\
\hline 2 & $\begin{array}{c}\text { PET:PBT } \\
80: 20\end{array}$ & $53 \pm 1$ & $75 \pm 0.5$ & $2305 \pm 20$ & $38 \pm 1$ & $72 \pm 0.5$ \\
\hline 3 & $\begin{array}{c}\text { PET:PBT } \\
70: 30\end{array}$ & $51 \pm 0.5$ & $70 \pm 1$ & $2151 \pm 15$ & $36 \pm 1$ & $68 \pm 0.5$ \\
\hline 4 & $\begin{array}{c}\text { PET:PBT } \\
60: 40\end{array}$ & $58 \pm 1$ & $78 \pm 1$ & $2287 \pm 10$ & $44 \pm 1.5$ & $67 \pm 0.5$ \\
\hline 5 & $\begin{array}{c}\text { PET:PBT } \\
50: 50\end{array}$ & $62 \pm 1.5$ & $73 \pm 0.5$ & $2457 \pm 20$ & $52 \pm 1.5$ & $65 \pm 1$ \\
\hline 6 & $\begin{array}{c}\text { PET:PBT } \\
40: 60\end{array}$ & $59 \pm 0.5$ & $76 \pm 1$ & $2321 \pm 15$ & $42 \pm 1$ & $60 \pm 0.5$ \\
\hline 7 & $\begin{array}{c}\text { PET:PBT } \\
20: 80\end{array}$ & $57 \pm 1$ & $73 \pm 1$ & $2345 \pm 10$ & $40 \pm 1$ & $59 \pm 0.5$ \\
\hline 8 & PBT 100 & $55 \pm 0.5$ & $75 \pm 0.5$ & $2127 \pm 5$ & $27 \pm 0.5$ & $56 \pm 1$ \\
\hline
\end{tabular}


TAble 2: Tensile, FleXural, Impact AND HDT data of Polypropylene/Thermoplastic POLYester blend

\begin{tabular}{|c|c|c|c|c|c|c|}
\hline No. & Compositions (wt \%) & $\begin{array}{c}\text { Tensile strength } \\
\text { (MPa) }\end{array}$ & $\begin{array}{l}\text { Flexural strength } \\
\text { (MPa) }\end{array}$ & $\begin{array}{l}\text { Flexural modulus } \\
\text { (MPa) }\end{array}$ & $\begin{array}{l}\text { Impact strength } \\
(\mathrm{J} / \mathrm{m})\end{array}$ & $\operatorname{HDT}\left({ }^{\circ} \mathrm{C}\right)$ \\
\hline 1 & PET 100 & $56 \pm 0.5$ & $76 \pm 0.5$ & $2105 \pm 10$ & $25 \pm 0.5$ & $78 \pm 1$ \\
\hline 2 & PBT 100 & $55 \pm 0.5$ & $75 \pm 0.5$ & $2127 \pm 5$ & $27 \pm 0.5$ & $56 \pm 1$ \\
\hline 3 & PP 100 & $32 \pm 1$ & $32 \pm 1$ & $1066 \pm 20$ & $36 \pm 1$ & $64 \pm 1$ \\
\hline 4 & PET:PBT 50:50 & $62 \pm 1.5$ & $73 \pm 0.5$ & $2457 \pm 20$ & $52 \pm 1.5$ & $65 \pm 1$ \\
\hline 5 & PP:PET 75:25 & $33 \pm 1$ & $44 \pm 1$ & $1656 \pm 5$ & $30 \pm 1$ & $69 \pm 1$ \\
\hline 6 & PP:PBT 75:25 & $30 \pm 2$ & $46 \pm 0.5$ & $1674 \pm 5$ & $33 \pm 1$ & $68 \pm 0.5$ \\
\hline 7 & $\begin{array}{c}\text { TERNARY BLEND I } \\
\text { PP:PET:PBT } \\
75: 12.5: 12.5\end{array}$ & $34 \pm 1$ & $48 \pm 1$ & $1743 \pm 10$ & $35 \pm 1.5$ & $65 \pm 1$ \\
\hline 8 & $\begin{array}{c}\text { TERNARY BLEND II } \\
\text { PP:PET:PBT } \\
50: 25: 25\end{array}$ & $38 \pm 1$ & $36 \pm 0.5$ & $1837 \pm 10$ & $27 \pm 0.5$ & $66 \pm 0.5$ \\
\hline
\end{tabular}

TABLE 3: THERMAL CHARACTERIZATION DATA FOR POLYPROPYLENE /THERMOPLASTIC POLYESTERS BLENDS

\begin{tabular}{|c|c|c|c|c|c|c|c|c|c|c|c|c|}
\hline \multirow[t]{2}{*}{$\begin{array}{l}\text { Compositions } \\
\text { (wt \%) }\end{array}$} & \multicolumn{3}{|c|}{$\begin{array}{l}\text { Melting temperature } \\
\qquad\left({ }^{\circ} \mathrm{C}\right)\end{array}$} & \multicolumn{3}{|c|}{$\begin{array}{l}\text { Heat of fusion } \\
\qquad \begin{array}{c}\Delta \mathrm{H}_{\mathrm{m}} \\
(\mathrm{J} / \mathrm{g})\end{array}\end{array}$} & \multicolumn{3}{|c|}{$\begin{array}{c}\text { Temperature } \\
\text { of crystallization } \\
\left({ }^{\circ} \mathrm{C}\right)\end{array}$} & \multicolumn{3}{|c|}{$\begin{array}{c}\begin{array}{c}\text { Heat } \\
\text { of }\end{array} \\
\text { crystallization } \\
\Delta \mathrm{H}_{\mathrm{c}} \\
(\mathrm{J} / \mathrm{g})\end{array}$} \\
\hline & PET & PBT & PP & PET & PBT & PP & PET & PBT & PP & PET & PBT & PP \\
\hline PET 100 & 246 & - & - & 56 & - & - & 151 & - & - & 50 & - & - \\
\hline PBT 100 & - & 229 & - & - & 48 & - & - & 179 & - & - & 43 & - \\
\hline PP 100 & - & - & 170 & - & - & 75 & - & - & 102 & - & - & 92 \\
\hline $\begin{array}{c}\text { PET:PBT } \\
50: 50 \\
\end{array}$ & 247 & 222 & - & 15 & 10 & - & \multicolumn{2}{|c|}{160} & - & 38 & - & - \\
\hline $\begin{array}{c}\text { PP:PET } \\
75: 25 \\
\end{array}$ & 252 & - & 167 & 7 & - & 78 & 192 & - & 113 & 4 & - & 74 \\
\hline $\begin{array}{c}\text { PP:PBT } \\
75: 25\end{array}$ & - & 226 & 167 & - & 9 & 70 & - & 191 & 120 & - & 5 & 72 \\
\hline $\begin{array}{c}\text { TERNARY } \\
\text { BLEND I } \\
\text { PP:PET:PBT } \\
75: 12.5: 12.5 \\
\end{array}$ & 247 & 223 & 168 & 3.5 & 2.5 & 75 & & & 119 & & & 74 \\
\hline $\begin{array}{c}\text { TERNARY } \\
\text { BLEND II } \\
\text { PP:PET:PBT } \\
\text { 50:25:25 }\end{array}$ & 250 & 223 & 168 & 8 & 5 & 45 & & & 118 & & & 45 \\
\hline
\end{tabular}


Yanbu Journal of Engineering and Science Vol. 14 (2017)

TABLE 4: CRYSTALLINITY DATA FOR POLYPROPYLENE /THERMOPLASTIC POLYESTERS BLENDS

\begin{tabular}{|c|c|c|c|c|c|c|}
\hline \multirow{2}{*}{ Compositions (wt \%) } & \multicolumn{3}{|c|}{ Heat of fusion $\Delta \mathrm{H}_{\mathrm{m}}(\mathrm{J} / \mathrm{g})$} & \multicolumn{3}{|c|}{ Crystallinity (\%) } \\
\hline & PET & PBT & PP & PET & PBT & $\mathrm{PP}$ \\
\hline PET 100 & 56 & - & - & 40 & - & - \\
\hline PBT 100 & - & 48 & - & - & 34 & - \\
\hline PP 100 & - & - & 75 & - & - & 37 \\
\hline PET:PBT 50:50 & 15 & 10 & - & 11 & 7 & - \\
\hline PP:PET 75:25 & 7 & - & 78 & 5 & - & 38 \\
\hline PP:PBT 75:25 & - & 9 & 70 & - & 6.5 & 34 \\
\hline $\begin{array}{c}\text { TERNARY BLEND } \\
\text { PP:PET:PBT } \\
75: 12.5: 12.5\end{array}$ & 3.5 & 2.5 & 75 & 2.5 & 2 & 37 \\
\hline $\begin{array}{c}\text { TERNARY BLEND } \\
\text { PP:PET:PBT } \\
50: 25: 25\end{array}$ & 8 & 5 & 45 & 6 & 4 & 22 \\
\hline
\end{tabular}

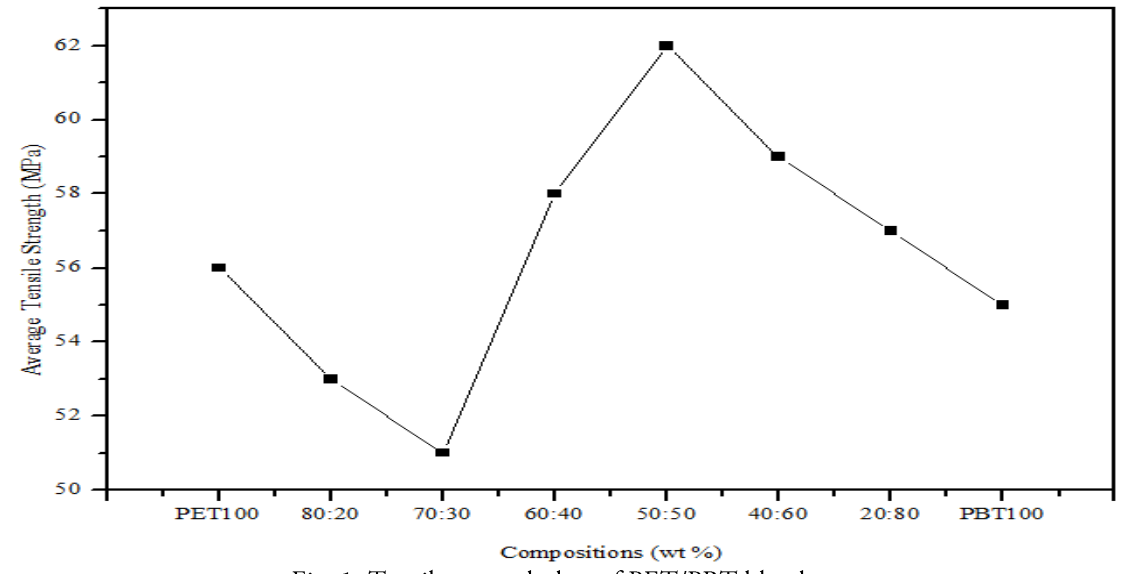

Fig. 1. Tensile strength data of PET/PBT blends.

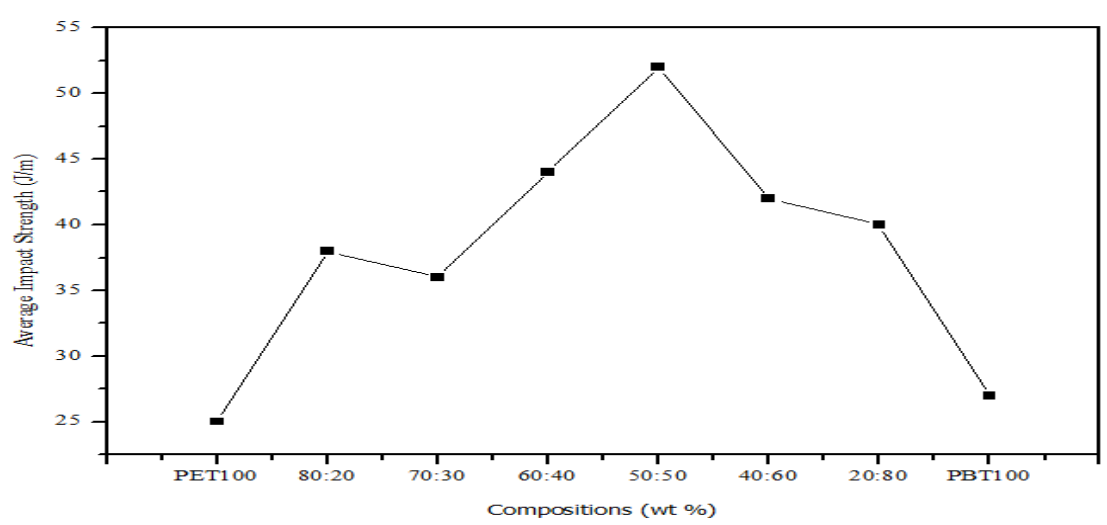

Fig. 2. Impact strength data of PET/PBT blends. 


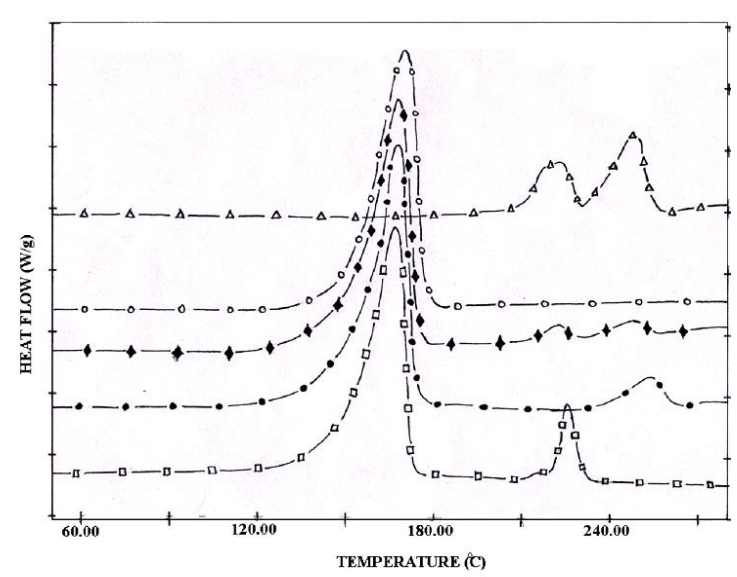

Fig. 3. DSC heating thermograms of Polypropylene/Thermoplastic polyesters blends

$(\mathrm{O})$ PP, $(\Delta)$ PET: PBT $(50: 50),(\bullet)$ PP: PET (75:25), ( $\square$ PP: PBT $(75: 25)$ and $(\bullet)$ PP:PET:PBT $(75: 12.5: 12.5)$

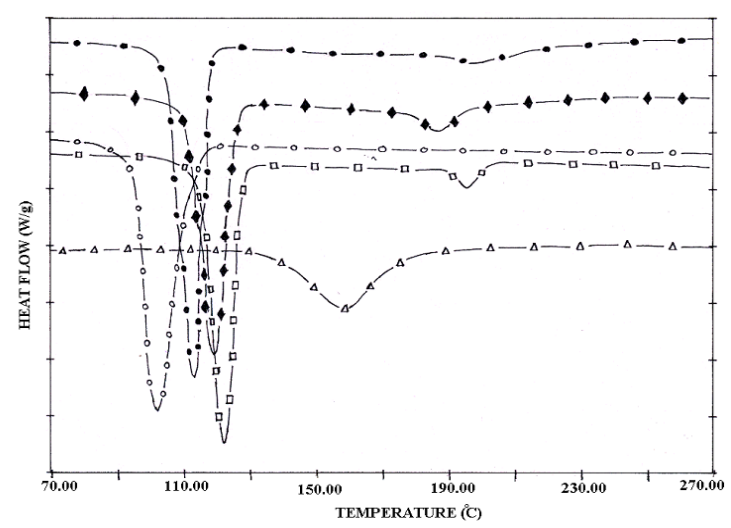

Fig. 4. DSC cooling thermograms of Polypropylene/Thermoplastic polyesters blends

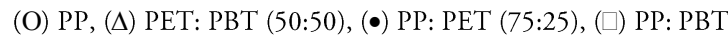
(75:25) and $(\bullet$ PP:PET:PBT (75:12.5:12.5)

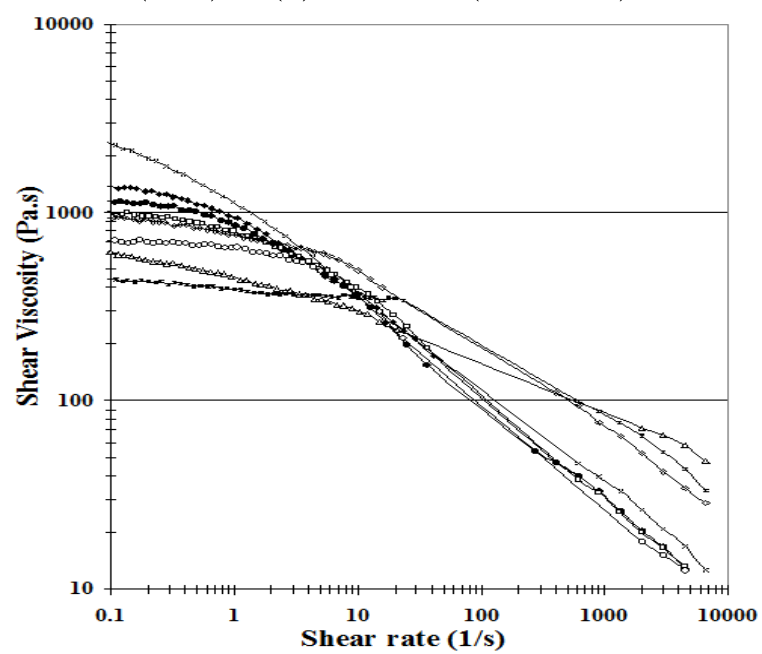

Fig. 5. Shear viscous behavior of $\mathrm{PP} /$ Thermoplastic polyesters blends at $260^{\circ} \mathrm{C}(\diamond)$ PET, (*) PBT, (O) PP, $(\Delta)$ PET: PBT 50:50, (•) PP: PET (75:25), (口) PP: PBT (75:25), (•) PP:PET:PBT (75:12.5:12.5) and $(\times)$ PP:PET:PBT (50:25:25)

\subsection{Rheological Properties}

Figure 5 shows variation of melt viscosity of $\mathrm{PP} /$ thermoplastic polyesters blends at $260^{\circ} \mathrm{C}$. It is clear that viscosity of PET is higher than that of PBT. The viscosity of PP is higher than that of PBT but lower than that of PET. PET:PBT (50:50) blend viscosity lies inbetween that of PET and PBT. The viscosity of $\mathrm{PP} /$ thermoplastic polyesters blends lies in the increasing order of PP:PBT (75:25), PP:PET (75:25), ternary blend I and ternary blend II. Viscosity of blends of polyesters is appreciably higher than that of PP in the low shear rate region. At high shear rates, the ternary blends are comparable. Therefore for extrusion and injection molding applications, both binary blends and PP are potentially better. However at low shear rates the viscosity of ternary blends are much higher than that of binary blends and PP alone, which shows its suitability for thermoforming processing technique.

\subsection{SEM MORPHOLOGY}

Figure 6 shows scanning electron photomicrographs for $\mathrm{PP} /$ thermoplastic polyester binary and ternary blends. SEM image of ternary blend I illustrate that thermoplastic polyesters droplets are uniformly dispersed in the polypropylene matrix compared to that of binary and ternary II blends. In ternary blend I, the homogenous dispersion of thermoplastic polyesters in PP leads better interaction of these thermoplastic polyesters phase with the PP matrix phase and thereby contributes to overall improvement of mechanical properties compared to that of binary and ternary II blends. 


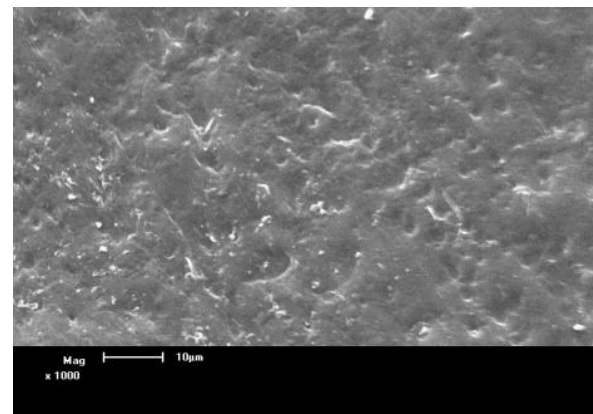

Fig.6(a) PP: PET(75:25) SEM photomicrographs of $\mathrm{PP} /$ Thermoplastic polyesters blends (Magnification $\approx 1000 \mathrm{x}$ )

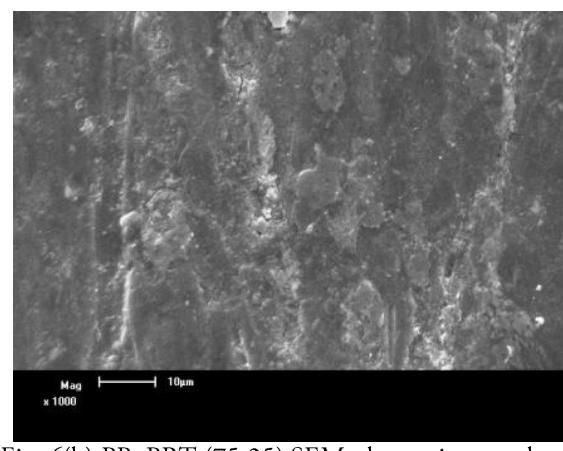

Fig. 6(b) PP: PBT (75:25) SEM photomicrographs of $\mathrm{PP} /$ Thermoplastic polyesters blends (Magnification $\approx 1000 \mathrm{x}$ )

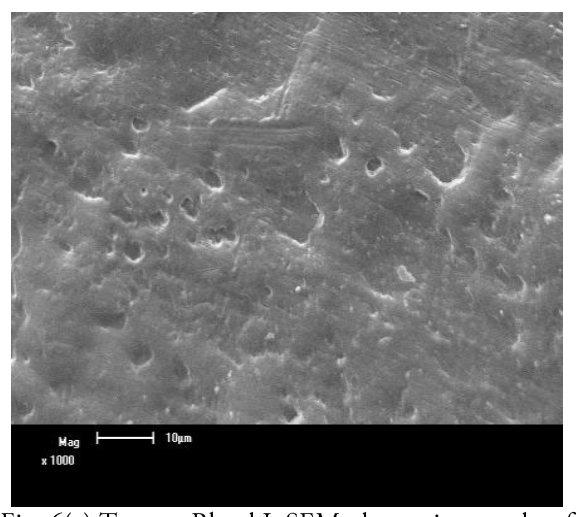

Fig. 6(c) Ternary Blend I. SEM photomicrographs of $\mathrm{PP} /$ Thermoplastic polyesters blends (Magnification $\approx 1000 \mathrm{x}$ )

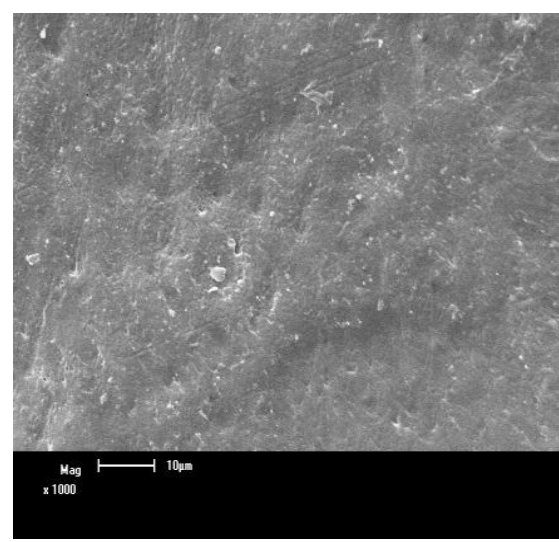

Fig. 6(d) Ternary Blend II SEM photomicrographs of $\mathrm{PP} /$ Thermoplastic polyesters blends (Magnification $\approx 1000 \mathrm{x}$ )

\section{CONCLUSION}

Polypropylene/Thermoplastic polyesters blends were prepared by melt blending technique. Ternary blends prepared by incorporation of thermoplastic polyesters into polypropylene exhibited better mechanical and thermal properties compared to homopolymers and binary blends. Presence of thermoplastics polyesters in ternary I blend improves flexural strength and flexural modulus than that of PP and existence of PP in ternary I blends improves impact strength compared to that of PET and PBT. Addition of thermoplastic polyesters with polypropylene accelerates its crystallization process. SEM study of ternary I blend showed uniform dispersion of polyester droplets in the polypropylene matrix that contributed for its overall improvement of mechanical properties. The very high viscosity at low shear rates and viscous behavior of ternary blends potentially suitable for thermoforming applications.

\section{REFERENCES}

[1] Utracki, L. A., Polymer blends, Vol. 11. iSmithers Rapra Publishing, 2000.

[2] Mittal, V., Functional polymer blends: synthesis, properties, and performance, CRC Press, 2012.

[3] Xanthos, M., Young, M. W., and Biesenberger, J. A., Polypropylene/polyethylene terephthalate blends compatibilized through functionalization, Polymer Engineering \& Science, 30, 355-365, 1990.

[4] Shertukde, V. V., and Kale, D. D., Blends of high density polyethylene and polyethylene terephthalate, Journal of Polymer Materials, 18, 119-126, 2001.

[5] Tao, Y., and Mai, K., Non-isothermal crystallization and melting behavior of compatibilized polypropylene/recycled poly (ethylene terephthalate) blends, European Polymer Journal, 43, 3538-3549, 2007.

[6] Yi, X., Ling X., Yu L. W., Gan J. Z., Xu J., and Zhong M. L.., Morphology and properties of isotactic polypropylene/poly (ethylene terephthalate) in situ microfibrillar reinforced 
blends: Influence of viscosity ratio,European Polymer Journal, 46, 719-730, 2010.

[7] Champagne, M. F., Michel A. Huneault, C. R., and Wilfried P., Reactive compatibilization of polypropylene/polyethylene terephthalate blends, Polymer Engineering \& Science, 39, 976-984, 1999.

[8] Jain, P., Ashok M., and Anup K. G., Compatibilization of polypropylene and polybutylene terephthalate blends using reactive extrusion: Mechanical properties, morphological and rheological studies, Journal of Polymer Materials, 18, 341, 2001.

[9] Subramanian, P. M., and Mehra. V., Laminar morphology in polymer blends: Structure and properties, Polymer Engineering \& Science, 27, 663-668, 1987.

[10] Bataille, P., Boisse, S., and Schreiber, H. P., Mechanical properties and permeability of polypropylene and poly (ethylene terephthalate) mixtures, Polymer Engineering \& Science, 27, 622-626, 1987.

[11] Xanthos, M., Young, M. W., and Biesenberger, J. A., Polypropylene/polyethylene terephthalate blends compatibilized through functionalization, Polymer Engineering \& Science, 30, 355-365, 1990.

[12] Vainio, T., Guo H. H., Morand L., and Jukka V. S., Functionalized polypropylene prepared by melt free radical grafting of low volatile oxazoline and its potential in compatibilization of PP/PBT blends, Journal of Applied Polymer Science, 61, 843-852, 1996.

[13] Bae, T. Y., Kang Y. P., Dong H. K., and Kyung D. S., Poly (ethylene terephthalate)/polypropylene reactive blends through isocyanate functional group, Journal of Applied Polymer Science, 81, 1056-1062, 2001.

[14] Kim, D. H., Kang Y. P., Ju Y. K., and Kyung D. S., Improved compatibility of high-density polyethylene/poly (ethylene terephthalate) blend by the use of blocked isocyanate group, Journal of Applied Polymer Science, 78, 1017-1024, 2000.

[15] Børve, K. L., Kotlar, H. K., and Gustafson, C.G., Polypropylene-phenol formaldehyde-based compatibilizers. II. Application in PP/PA6 75/25 (wt/wt) blends. Journal of Applied Polymer Science, 75, 355-360, 2000.

[16] Basu, S., and Kale D.D., Processing of high density polyethylene and poly (ethylene terephthalate) blends, Macromolecular Symposia, 118, 329-334, 1997.

[17] Shieh, Y. T., Tzong N. L., and Feng C. C., Reactive compatibilization of PP/PBT blends by a mixture of PP-g-MA and epoxy resin, Journal of Applied Polymer Science, 79, 2272-2285, 2001.

[18] Pesneau, I., Cassagnau,P. and Michel A., Morphology monitoring of PE/PBT blends by reactive processing, Journal of Applied Polymer Science, 82, 3568-3577, 2001.

[19] Zhang, H. X., and Hourston, D. J., Reactive compatibilization of poly (butylene terephthalate)/low-density polyethylene and poly (butylene terephthalate)/ethylene propylene diene rubber blends with a bismaleimide, Journal of Applied Polymer Science, 71, 2049-2057, 1999.

[20] Tsai, C. H., and Feng C. C., Polymer blends of PBT and PP compatibilized by ethylene-coglycidyl methacrylate copolymers, Journal of Applied Polymer Science, 61, 321-332, 1996.

[21] Heino, M., Kirjava, J. and Hietaoja, P., Compatibilization of polyethylene terephthalate/polypropylene blends with styreneethylene/butylene-styrene (SEBS) block copolymers, Journal of Applied Polymer Science, 65, 241-249, 1997.

[22] Carte, T. L., and Abdelsamie M., Morphological origin of super toughness in poly (ethylene terephthalate)/polyethylene blends,Journal of Applied Polymer Science, 48, 611-624, 1993.

[23] Pluta, M., Zbigniew B., Andrzej P., Andrzej G., and Mariano P., Phase structure and viscoelastic properties of compatibilized blends of PET and HDPE recyclates, Journal of Applied Polymer Science, 82, 1423-1436, 2001.

[24] Ignaczak, W., Kinga W., Jolanta J., and Mirosława E. F., Mechanical and thermal properties of PP/PBT blends compatibilized with triblock thermoplastic elastomer, Polish Journal of Chemical Technology, 17, 78-83, 2015.

[25] Joshi, M., Maiti, S. N., and Misra, A., Poly (butylene terephthalate)/high density polyethylene alloys. II. Mechanical properties and rheology, Journal of Applied Polymer Science,45, 1837-1847 1992.

[26] Chiu, H. T. and Yao, K. H., Compatibilization of poly (ethylene terephthalate)/polypropylene blends with maleic anhydride grafted polyethylene-octene elastomer, Journal of Polymer Research, 13, 153-160, 2006. 
[27] Traugott, T. D., Barlow,J. W. and Paul, D.R., Mechanical compatibilization of high density polyethylene-poly (ethylene terephthalate) blends, Journal of Applied Polymer Science, 28 (9), 2947-2959, 1983.

[28] Guerrero, C., Tomas L., Virgilio G., and Eliud A., Properties and morphology of poly (ethylene terephthalate) and high-density polyethylene blends, Journal of applied polymer science, 82 (6), 1382-1390, 2001.

[29] Boutevin, B., Lusinchi J. M., Pietrasanta, Y.,, and Robin, J.J., Improving poly (ethylene terephthalate)/high-density polyethylene blends by using graft copolymers, Polymer Engineering \& Science, 36 (6), 879-884, 1999.

[30] Liang, N.Y., Trong M. D., Chih Y. H., and Wen Y. C., Fiber and film developments from immiscible blends of cellulose acetate propionate and poly (butylene terephthalate). Journal of Applied Polymer Science, DOI:10.1002/app.45013, 2017.

[31] Mishra, S. P., and Deopura, B.L., Theoretical predictions of compatibility of poly (ethylene terephtalate) and poly (butylene terephthalate) blends, Polymer Communications, 26, 5-7, 1985.

[32] Mishra, S. P., and Deopura, B. L., Fibers from poly (ethylene terephthalate) and poly (butylene terephthalate) blends I. Mechanical behavior, Journal of Applied Polymer Science, 33, 759-768, 1987.

[33] Stein, R. S., Khambatta, F. B. , Warner, F. P. , Russell, T., Escala, A., and Balizer, E., X-ray and optical studies of the morphology of polymer blends, Journal of Polymer Science: Polymer Symposia, 63, 313-328, 1978.
[34] Avramova, N., Amorphous poly (ethylene terephthalate)/poly (butylene terephthalate) blends: miscibility and properties, Polymer, 36, 801-808 1995 .

[35] Tao, J., Jin, H-F., and Sun, T., A Study on Compatibility of PBT/PET Binary Blended Fibre,Plastics, Rubber and Composites Processing and Applications, 16, 49-53, 1991.

[36] Francesco, P. L. M., Manuela C., Gaia G., Maria C. M., and Luigi B., Effect of a Compatibilizer on the Morphology and Properties of Polypropylene/Polyethylentherephthalate Spun Fibers, Polymers, 9 (2), 47, 2017.

[37] Aravinthan, G., and Kale, D. D., Blends of poly (ethylene terephthalate) and poly (butylene terephthalate), Journal of Applied Polymer Science,98, 75-82, 2005.

[38] Oyman, Z. O., and Tincer, T., Melt blending of poly (ethylene terephthalate) with polypropylene in the presence of silane coupling agent, Journal of Applied Polymer Science, 89, 1039-1048, 2003.

[39] Stokke, D. D., and Gardner, D. J., Fundamental aspects of wood as a component of thermoplastic composites, Journal of Vinyl and Additive Technology, 9(2), 96-104, 2004.

[40] Cheng, S. Z., ed. Handbook of thermal analysis and calorimetry: Applications to polymers and plastics. Vol. 3. Elsevier, 2002. 
تأثير مزج الثيرموبلاستيك والبوليستر على الخصائص الميكانيكية، الحرارية والريولوجية للبوليبروبيلين أر افينثان جوبانا 1، ومورثي تشافالي 2

1 مركز ينبع للبحوث، قطاع الكليات والمعاهد، الهيئة الملكية بينبع، المملكة العربية السعودية 22 مركز التميز في مختبرات المتقدمة للمواد ، اندهر اء بر ادش، الهند

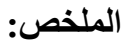

الغرض من البحث هو تحضير ودراسة خصائص مزيج ثلاثى يتكون من بولي بروبيلين مع [بولي (الإيثلين تيريفتالات) / بولي (بوتيلين تيريفتالات)] يمزج مع نسبة من بولي (الإثليلين تيريفنالات) الى بولي (بوتيلين تيريفتالات) بنسبه تركيز 0.1 حيث يتم تكوين مخلوط (ثلاثي المزج) من المركب [بولي (الإيثلين تيريفتالات ) / بولييروبيلين وبولي (بوتيلين تبريفتالات)] مع مزيج من [البولي بروبلين و البولي (الإيثيلين تيريفثالات) / بولي (بوتيلين تيريفنالات) / البولي بروبلين] ثلاثيه المزج تم بو اسطة استخدام طارد ثنانى حلزونى مشترك. ويستخدم حمض الاكريليك أكريليك و البولي بروبيلين المطعم كماده مازجه (PP-g-AA) تمت دراسة الخصائص الميكانيكه و الحرارية والريولوجيه والسلوك المورفولوجي للمزج الثنائي والثلاثي. أكدت النتائج أن المزج الثثلاثى يظهر تحسن الخصائص الميكانيكية والحرارية بالمقارنة مع مزيج [بولي (إيثيلين تيريفتالات) / بولي بروبيلين ومزيج بولي (بوتيلين تيريفتالات) / بولي بروبيلين] كمزيج، ووجد ان السلوك الريولوجي للمزيج الثلاثي ذات اللزوجة العالية عند معدل قص منخفض مفيد لتطبيقات التثكيل الحر اري. 